\title{
Isotherm and Kinetic Modeling of Cd(II) Uptake from Aqueous Solutions using an Agri-Waste Biosorbent Jute Stick Powder
}

\author{
Jahangir Alam¹, A. K. M. Atique Ullah², Mohammad Nasir Uddin ${ }^{1 *}$ (D) \\ ${ }^{1}$ Department of Chemistry, University of Chittagong, Chittagong 4331, Bangladesh \\ ${ }^{2}$ Nanoscience and Technology Research Laboratory, Chemistry Division Bangladesh Atomic Energy Commission, \\ Dhaka-1000, Bangladesh
}
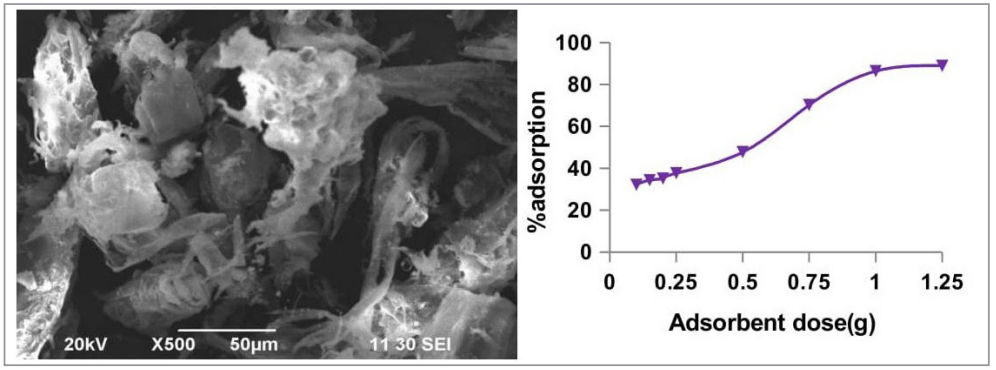

The removal of cadmium(II) from aqueous solutions in a batch system was conducted by using an agri-waste biomass Jute Stick Powder (JSP). To optimize parameters like metal concentration, solution $\mathrm{pH}$, adsorbent amount, contact time and agitation speed, batch experiments were conducted. Further experiments were performed, using optimized conditions at $\mathrm{pH} 4.5$, adsorbent dosages of $0.5 \mathrm{~g} / 100 \mathrm{~mL}$, a contact time of $60 \mathrm{~min}$ and shaking speed of $180 \mathrm{rpm}$. Favorable adsorption occurred at around $\mathrm{pH} 4.5$, with a maximum adsorption capacity of $10.003 \mathrm{mg} \mathrm{g}^{-1}$. Detailed analysis has been conducted by testing kinetic models such as pseudo-first-order and pseudo-second-order models to determine the sorption rate and mechanism. The adsorption process was confirmed by various isotherm models and experimental data for $\mathrm{Cd}(\mathrm{II})$ biosorption fitted well to the Freundlich isotherm model at room temperature and under optimum conditions. Positive values of the thermodynamic parameter $\Delta G$ assumed that the metal adsorption process was spontaneous. JSP can be used repeatedly more than three times with a small efficiency loss. Experimental data plotted to the isotherm and kinetic models confirms that JSP can be used as a potential biosorbent for the successful removal of $\mathrm{Cd}(\mathrm{II})$ ions from waste water.

Key words: Jute Stick Powder (JSP), lingo-cellulosic, cadmium(II), Freundlich isotherm, pseudo-first-order.

\section{INTRODUCTION}

Heavy metals are a threat to human life and the environment. Toxic heavy metals, such as cadmium $(\mathrm{Cd})$, lead $(\mathrm{Pb})$, zinc $(\mathrm{Zn})$, mercury $(\mathrm{Hg})$, arsenic $(\mathrm{As})$, silver $(\mathrm{Ag})$, chromium $(\mathrm{Cr})$ and copper $(\mathrm{Cu})$, are discharged into the environment by both anthropogenic activities and natural circumstances. A very important problem worldwide is water contamination with heavy metals. These heavy metals are persistent in nature and non-biodegradable, causing toxicity via bioaccumulation in animal cells. Cadmium is one of the most toxic heavy metals, having a half-life of 10-30 years. It enters the food cycles and remains

Cite: Alam, J.; Atique Ullah, A. K. M.; Uddin, M. N. Isotherm and Kinetic Modeling of Cd(II) Uptake from Aqueous Solutions using an Agri-Waste Biosorbent Jute Stick Powder. Braz. J. Anal. Chem., 2020, 7 (28), pp 31-43. doi: http://dx.doi.org/10.30744/ brjac.2179-3425.AR-20-2020 
in the kidney, liver and other vital organs for a long time. Once taken up by the blood, the majority of cadmium is transported to proteins, inducing the production of Metallothionein in the liver. Kidney damage, bone and renal disease, lung and renal dysfunction, cancer and cardiovascular diseases, hypertension, and chronic anemia are common diseases caused by cadmium toxicity [1]. Electroplating, smelting, alloy manufacturing, pigments, plastic, battery, mining and refining processes are the main sources of cadmium pollution in the environment. Hence, it is necessary to remove cadmium from industrial water before discharge into the water body.

To remove toxic metals from water, a number of conventional methods are available, including ion exchange, reverse osmosis, precipitation, solvent extraction, membrane technologies, electrochemical treatment, and adsorption. The adsorption process employed for materials of biological origin is called biosorption; this is a very attractive method to researchers currently. Because conventional methods have some drawbacks such as high operational costs, the requirement for new reagents and the production of sludge as a secondary pollutant which needs to be treated, they can be alternated with biosorption, which is cost effective, easy to operate and environmentally friendly. Widely used cheap agricultural wastes to remove $\mathrm{Cd}$ from aqueous solutions include rice straw [2], leaf biomass of the sodom apple [3], tea waste [4], rice bran [5], and loquat leaves [6]. Jute stick is one of the most abundant lingo-cellulosic agricultural waste by-products of jute fiber, which is the main cash crop of Bangladesh. In continuation of our previous project, JSP has been applied for the removal of $\mathrm{Cr}(\mathrm{III})$ and $\mathrm{Pb}(\mathrm{II})$ ions from aqueous solutions $[7,8]$.

The aim of this work is to study the biosorption of $\mathrm{Cd}(\mathrm{II})$ ions onto jute stick powder as a low cost and extensively available biomass. Different biosorption controlling factors such as the initial solution $\mathrm{pH}$, temperature, contact time, and metal ion concentration on the adsorption isotherm were examined to optimize the adsorption process. Sorption capacity was tested by plotting some isotherm models and sorption mechanism was studied by plotting kinetic equations.

\section{MATERIAL AND METHODS \\ Preparation of biosorbent}

After the separation of jute fibers, the inner woody fiber stick is left, which is then dried in the sunlight. These jute stick biomasses were collected and chopped into small pieces. After that, the biomass was washed with water to remove any adhering substances and dried at $80^{\circ} \mathrm{C}$ in an oven for 12 hours. Finally, it was powdered by grinding manually by a kitchen grinder. To obtain a uniform size particle, the powder was sieved and 80-100 mesh size fractions were used for subsequent study.

\section{Preparation of synthetic waste water}

The stock solution (1000 $\mathrm{mg} \mathrm{L}^{-1}$ ) of $\mathrm{Cd}(\mathrm{II})$ was prepared by dissolving $2.751 \mathrm{~g}$ of cadmium nitrate tetrahydrate $\left[\mathrm{Cd}\left(\mathrm{NO}_{3}\right)_{2} \cdot 4 \mathrm{H}_{2} \mathrm{O}\right]$ in $1000 \mathrm{~mL}$ of double-distilled water. The working solutions were prepared by the dilution of the stock solution and were used throughout the experiment. The $\mathrm{pH}$ of the waste water was adjusted by using $0.1 \mathrm{M} \mathrm{NaOH}$ and $0.1 \mathrm{M} \mathrm{HCl}$ solution and was tested by a digital pH meter (HANNA, HI2209). All of the chemicals were of analytical grade and purchased from Merck Company (Germany).

\section{Batch biosorption studies}

\section{Equilibrium isotherm studies}

Equilibrium isotherm studies were conducted using $100 \mathrm{~mL}$ fixed volume solutions with a range of concentrations in $250 \mathrm{~mL}$ conical flasks mixed with an optimum biosorbent dose of $0.5 \mathrm{~g}$ and then agitated for 60 minutes at shaking speed $180 \mathrm{rpm}$ by a reciprocating orbital shaker. After completion of shaking the solutions were filtered by Whatman ${ }^{\mathrm{TM}}$ filter paper. Biosorption experiments were conducted at room temperature $\left(28^{\circ} \mathrm{C}\right)$ and the concentration of the metal was determined by an atomic absorption spectrophotometer (AA7000, SHIMADZU, Japan) with Cd hollow cathode lamp and air acetylene flame. It is important to consider that all of the experiments were replicated three times and the mean of the data was used to determine the result. 


\section{Effect of contact time}

Batch biosorption experiments were conducted at different time periods $(5,15,25,35,60,90$ and 120 $\min )$ at $\mathrm{pH} 4.5$, the initial biosorbent concentration of $0.5 \mathrm{~g}$ in $100 \mathrm{~mL}$ solution, metal ion concentration of $50 \mathrm{mg} \mathrm{L}^{-1}$, and shaking speed of $180 \mathrm{rpm}$ at $28^{\circ} \mathrm{C}$. After shaking on a reciprocal shaker for a definite time period, the solution of the specified flask was taken out and filtered. The concentration of metal was determined by AAS.

\section{Effect of $\mathrm{pH}$}

To determine the influence of $\mathrm{pH}$ on the sorption of $\mathrm{Cd}(\mathrm{II})$ by batch process, $100 \mathrm{~mL}$ of $50 \mathrm{mg} \mathrm{L}^{-1} \mathrm{metal}$ solution was placed in a conical flask. Using $0.1 \mathrm{M} \mathrm{HCl}$ and $0.1 \mathrm{M} \mathrm{NaOH} \mathrm{pH}$ of the solution was adjusted and kept at $\mathrm{pH} 1$ to 10 ; the solutions were taken as $0.5 \mathrm{~g} \mathrm{JSP}$ in 10 flasks. Then, the flasks were shaken at rpm 180 for 60 minutes. Next, the residue was filtered and the final concentration of metal ions was determined by AAS.

\section{Influence of adsorbent dose}

The effect of the biosorbent dose on the adsorption capacity was investigated at $28{ }^{\circ} \mathrm{C}$ using a range of adsorbents $(0.10 \mathrm{~g}$ to $1.25 \mathrm{~g})$ at a constant $\mathrm{pH}$ of 4.5 and metal concentration of $50 \mathrm{mg} \mathrm{L}^{-1}$ in $100 \mathrm{~mL}$ of solution. Then, the mixtures were shaken at $180 \mathrm{rpm}$ for 60 minutes. When equilibrium was reached, the solutions were filtered. The concentration of metal ions was then determined by AAS.

\section{Calculation of Biosorption}

The amount of metal adsorbed by the biosorbent was calculated based on the mass balance for the biosorbent in the system as the metal uptake (biosorption capacity, q) to judge the quality of that biomass. Biosorption capacity (q) and metal sorption (\%) are calculated according to Equations 1 and 2.

$$
\begin{gathered}
q_{e}=\frac{V\left(C_{i}-C_{f}\right)}{S} \\
\text { \%Sorption }=\frac{C_{i}-C_{f}}{C_{i}} \times 100
\end{gathered}
$$

Where $\mathrm{q}_{\mathrm{e}}\left(\mathrm{mg} \mathrm{g}^{-1}\right)=$ metal ion uptake capacity, $\mathrm{C}_{\mathrm{i}}\left(\mathrm{mg} \mathrm{L}^{-1}\right)=$ initial concentration of metal in solution before the sorption analysis, $\mathrm{C}_{\mathrm{f}}\left(\mathrm{mg} \mathrm{L}^{-1}\right)=$ final concentration of metal in solution after the sorption analysis, $S(g)=$ dry weight of the biosorbent, and $V(L)=$ solution volume. The difference between the initial and final concentration of metal ions was assumed to be bound to the biosorbent.

\section{Mathematical modeling}

Isotherm models

At the equilibrium of an adsorption process, the distribution of adsorbate molecules between the liquid and the solid phase can be described mathematically by various adsorption isotherms [9]. Experimentally collected data were analyzed by using four adsorption isotherms: the Langmuir, Freundlich, Temkin and DubininRadushkevich (D-R) models. By calculating the isotherm parameters, some information such as adsorption mechanism, favorability of adsorption process and adsorbate-adsorbent affinity may be interpreted.

The Langmuir isotherm [10] describes equilibrium distribution of metal ions between the solid and liquid phases, the formation of an adsorbate monolayer, and uniform energies of adsorption onto the surface, is expressed by the mathematical relation in Equation 3.

$$
\frac{1}{q_{e}}=\frac{1}{q_{m}}+\frac{1}{q_{m} K_{L} C_{e}}
$$


Where $\mathrm{C}_{\mathrm{e}}$ is the equilibrium concentration of $\mathrm{Cd}(\mathrm{II})\left(\mathrm{mg} \mathrm{L}^{-1}\right), \mathrm{q}_{\mathrm{e}}$ is the quantity of $\mathrm{Cd}(\mathrm{II})$ adsorbed on to the adsorbent at equilibrium ( $\left.\mathrm{mg} \mathrm{g}^{-1}\right), \mathrm{q}_{\mathrm{m}}$ is the maximum monolayer adsorption capacity of adsorbent $\left(\mathrm{mg} \mathrm{g}^{-1}\right)$ and $\mathrm{K}_{\mathrm{L}}$ is the Langmuir adsorption constant $\left(\mathrm{L} \mathrm{mg}^{-1}\right)$. The plot of $1 / \mathrm{q}_{\mathrm{e}}$ against $1 / \mathrm{C}_{\mathrm{e}}$ gives a straight line with a slope and intercept of $1 / q_{m} \cdot K_{L}$ and $1 / q_{m}$, respectively. An important characteristic of the Langmuir isotherm is expressed by a dimensionless constant equilibrium parameter $R_{L}$, which is calculated from the value of $K_{L}$ in a range of initial concentrations $\left(20 \mathrm{mg} \mathrm{L}^{-1}\right.$ to $\left.100 \mathrm{mg} \mathrm{L}^{-1}\right)$. The $\mathrm{R}_{\mathrm{L}}$ value indicates the favorability of adsorption processes and is expressed by Equation 4 .

$$
R_{L}=\frac{1}{1+K_{L} C_{0}}
$$

According to Mckay et al. [16], the $R_{L}$ value indicates the adsorption nature to be either unfavorable if $R_{L}>1$, linear if $R_{L}=1$, and favorable if $0<R_{L}<1$.

The Freundlich isotherm [17] is an empirical model which is applicable to adsorption processes that occur on heterogonous surfaces. The linear form of the isotherm as an expression of heterogeneity and the exponential distribution of active sites and their energies can be given as follows:

$$
\log q_{e}=\log K_{F}+\frac{1}{n} \log C_{e}
$$

Where $\mathrm{K}_{\mathrm{F}}$ is a constant describing the adsorption capacity $\left(\mathrm{Lg}^{-1}\right)$ and $\mathrm{n}$ is an empirical parameter related to the adsorption intensity which can be determined from the plot of $\log _{\mathrm{e}}$ against $\log \mathrm{C}_{\mathrm{e}}$. According to Kadirvelu and Namasivayam [18], a value of $n$ between 1 and 10 represents a beneficial adsorption process.

The Temkin isotherm assumes the effects of indirect adsorbate/adsorbent interactions on the adsorption process ignoring extremely low and very high concentrations in the uniform distribution of bounding energy up to some maximum bonding energy [19]. The linear form of Temkin isotherm model is given by the following equation:

$$
\mathrm{q}_{\mathrm{e}}=\mathrm{Bln}_{\mathrm{T}}+\mathrm{Bln}_{\mathrm{e}}
$$

Where, $\mathrm{q}_{\mathrm{e}}$ is the amount of adsorbate adsorbed at equilibrium $\left(\mathrm{mg} \mathrm{g}^{-1}\right)$; $\mathrm{C}_{\mathrm{e}}$ is concentration of adsorbate in solution at equilibrium $\left(\mathrm{mg} \mathrm{L}^{-1}\right), B$ is a constant related to the heat of adsorption which is defined by the expression $B=R T / b, b_{T}$ is the Temkin constant $(\mathrm{J} / \mathrm{mol}), T$ is the absolute temperature $(K), R$ is the gas constant $(8.314 \mathrm{~J} / \mathrm{mol} / \mathrm{K})$, and $A$ is the Temkin isotherm constant $\left(\mathrm{L} \mathrm{g}^{-1}\right)$. From the plot of $\mathrm{q}_{\mathrm{e}} \mathrm{vs}$. $\ln \mathrm{C}_{\mathrm{e}}, \mathrm{B}$ and A can be calculated from the slopes $(B)$ and intercepts $(B \ln A)$ respectively.

The Dubinin Radushkevich (D-R) model gives information about biomass porosity as well as the adsorption energy which assumes that the adsorption process is physical or chemical in nature [20]. The model also presumes that adsorption is a multilayer character involving Van Der Waal's forces, applicable for physical adsorption processes following pore filing mechanism [21]. The D-R isotherm is expressed as follows:

$$
\begin{gathered}
\ln q_{e}=\ln q_{m}-K_{D} \varepsilon^{2} \\
\varepsilon=R \operatorname{Tln}\left(1+\frac{1}{C_{e}}\right)
\end{gathered}
$$

Where $\mathrm{q}_{m}$ and $\mathrm{K}_{\mathrm{D}}$ are the constants of $\mathrm{D}-\mathrm{R}$ isotherm model, respectively, the maximum adsorption capacity $\left(\mathrm{mol} \mathrm{g}^{-1}\right)$ and the adsorption energy. The constant $\mathrm{K}_{\mathrm{D}}$ is related to the mean free energy of sorption 
per mole of the adsorbent as it is moved from infinite distance in the solution to the surface of the biomass, $\mathrm{E}$, which can be calculated using the following equation:

$$
\mathrm{E}=\frac{1}{\left(2 K_{D}\right)^{\frac{1}{2}}}
$$

The values of $q_{m}$ and $K_{D}$ may be obtained from the slope and the intercept of Inqe versus $\varepsilon^{2}$ plot.

\section{Kinetic models}

To analyze possible $\mathrm{Cd}(\mathrm{II})$ metal adsorption rate controlling steps and possible mechanism kinetic models such as pseudo-first-order, a pseudo-second-order model was studied.

The pseudo first-order kinetic model of Lagergren [22] is given by Equation 10:

$$
\log \left(q_{e}-q_{t}\right)=\log q_{e}-\frac{k_{1}}{2.303} t
$$

Where, $\mathrm{q}_{\mathrm{e}}\left(\mathrm{mg} \mathrm{g}^{-1}\right)$ and $\mathrm{q}_{\mathrm{t}}\left(\mathrm{mg} \mathrm{g}^{-1}\right)$ are the adsorption amount at equilibrium and time $\mathrm{t}(\mathrm{min})$, respectively. $\mathrm{k}_{1}\left(\mathrm{~min}^{-1}\right)$ is the rate constant in the pseudo-first-order adsorption process. The constants were determined experimentally by plotting log $\left(q_{e}-q_{t}\right)$ versus $t$.

The pseudo-second-order kinetic model [23] can be presented as shown in Equation 11:

$$
\frac{t}{q_{t}}=\frac{1}{k_{2} q_{e}^{2}}+\frac{t}{q_{e}}
$$

Where $\mathrm{k}_{2}\left(\mathrm{~g} \mathrm{mg}^{-1} \mathrm{~min}^{-1}\right)$ is the rate constant of the second-order equation. A linear graph was obtained from the plot of $t / q_{t}$ versus $t$. The pseudo-second-order rate constants $k_{2}$ and $q_{e}$ were determined from the intercept and slope of the plot.

\section{RESULTS AND DISCUSSIONS \\ Characterization of biosorbent}

Constituents of JSP are mainly a-cellulose, hemicellulose, and lignin, containing some characteristic functional groups which are responsible for metal binding. To identify the functional groups in the JSP, FTIR experiments for raw and Cd(II) loaded JSP were performed in the same conditions. In the FTIR spectrum of raw JSP, a broad intense peak at $3296.52 \mathrm{~cm}^{-1}$ was assigned to stretching of OH groups. A high concentration of intermolecular $\mathrm{H}$-bonded phenol and alcohol is responsible for this broad band. The bands at $2872.13 \mathrm{~cm}^{-1}$ are most probably due to the contribution from the $\mathrm{C}-\mathrm{H}$ stretching of cellulose and hemicelluloses. The peak number at $1745 \mathrm{~cm}^{-1}$ is identical to C-O stretching of the carboxyl and acetyl groups in hemicelluloses of the JSP. The absorption band at around $1592 \mathrm{~cm}^{-1}$ is attributed to $\mathrm{C}=\mathrm{O}$ bonds [24]. For the contribution from various vibration modes, most bands are complex below the spectral region of $1400 \mathrm{~cm}^{-1}$ which is more difficult to analyze. A weak band at $1376 \mathrm{~cm}^{-1}$, which is seen in the spectrum due to symmetric $\mathrm{C}-\mathrm{H}$ deforming, may be attributed to lignin, $\alpha$-cellulose, or xylan. Again, the peaks observed at $1059 \mathrm{~cm}^{-1}$ and $1035.92 \mathrm{~cm}^{-1}$ are due to aromatic $\mathrm{C}-\mathrm{H}$ in plane deformation, $\mathrm{C}-\mathrm{O}$ deformation, $\mathrm{C}-\mathrm{C}$ stretching and $\mathrm{C}-\mathrm{OH}$ bending for primary alcohol in lignin and polysaccharides. A medium band peak $1234.50 \mathrm{~cm}^{-1}$ in the spectrum is ascribed to C-O stretching of acetyl in xylan [25]. The figure shows that over the spectral region $1000-1300 \mathrm{~cm}^{-1}$, carbohydrate originating vibrations are associated. However, peaks at 2333.00 and $2360.01 \mathrm{~cm}^{-1}$ in the spectrum might be due to noises obtained for flaws in the machine. 
The FTIR spectra of metal Cd(II) loaded JSP show that the spectral band at $3296.52 \mathrm{~cm}^{-1}$ became less intense and shifted to $3294.57 \mathrm{~cm}^{-1}$, which confirms the exchange of protons with metal ions. The peaks obtained for raw JSP at 2872.13, 1745.27, 1598.27 and $1059.93 \mathrm{~cm}^{-1}$ etc. had shifted to $2845.13,1743.31$, 1592.31, and $1057.04 \mathrm{~cm}^{-1}$, respectively, due to $\mathrm{Cd}(\mathrm{II})$ ion adsorption. The shifting of these spectral bands may be attributed to the changes in counter-ions associated with carboxylate and hydroxylate anions, suggesting that acidic groups, carboxyl and hydroxyl, are predominant contributors to metal ion uptake [26,27].

Figure 1 shows the scanning electron micrographs (SEM) of raw JSP and cadmium-loaded JSP at different magnifications. The presence of a few macropores of various irregular sizes at the surface of thread-nodule like JSP particles is clearly observed in the SEM image [Figure 1(a,b)]. After the adsorption of cadmium, significant changes in the surface morphology were noted. For example, uneven and irregular macropores in the surface and mineral matter might be trapped within these macropores [Figure 1(c, d)]. The presence of very distinguished multiple layers in SEM images of metal-loaded JSP could be taken as a sign for the effective adsorption of $\mathrm{Cd}(\mathrm{II})$ ions.

(a)

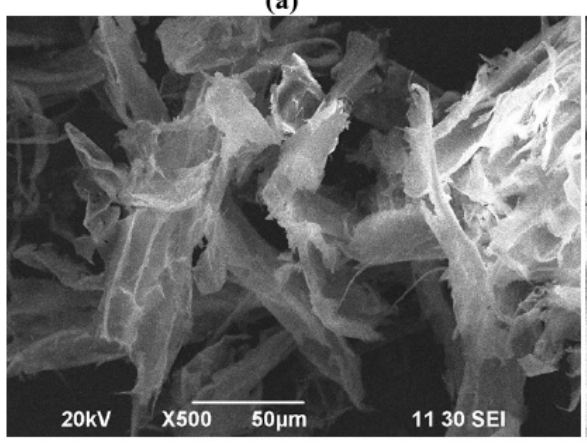

(c)

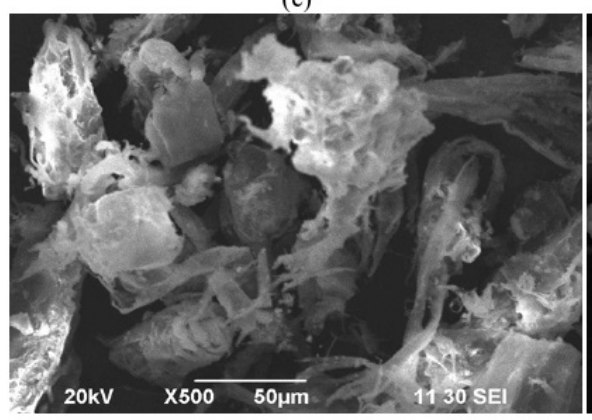

(b)

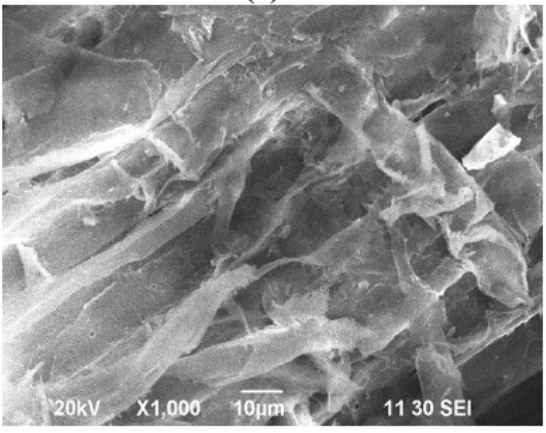

(d)

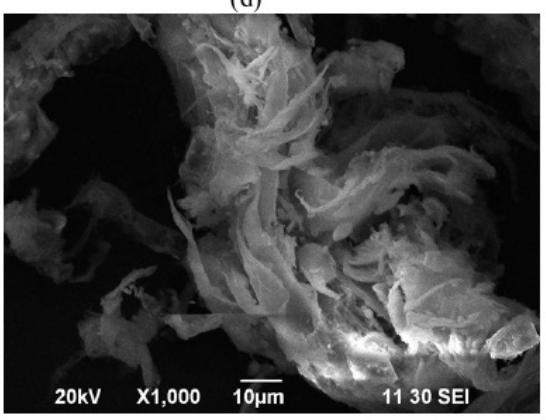

Figure 1. SEM images: $(a, b)$ is for raw JSP and $(c, d)$ is for Cd(II) ions loaded JSP.

\section{Optimization of influencing parameters}

Influence of $\mathrm{pH}$

$\mathrm{pH}$ is considered a key controlling parameter in the bio-sorption process of metal ions from aqueous solutions. The experimental data plotted in Figure 2(a) indicate that the adsorption of $\mathrm{Cd}(\mathrm{II})$ ions from the aqueous solution was very low at low $\mathrm{pH}$ values and increased sharply with the increase in $\mathrm{pH}$. The removal of $\mathrm{Cd}(\mathrm{II})$ was about $0.892 \%$ at $\mathrm{pH} 2.0$ and reached a maximum value $(54.29 \%)$ at about $\mathrm{pH} 4.0$. Further increases in $\mathrm{pH}$ from 4 to 10 lead to slight decreases in $\mathrm{Cd}(\mathrm{II})$ removal efficiency. Módenes et al. [9] reported that metal precipitation began to occur at $\mathrm{pH}$ 5.5. At low $\mathrm{pH}$ values, the uptake of $\mathrm{Cd}(\mathrm{II})$ was very low, because higher concentrations of $\mathrm{H}^{+}$ions competed with $\mathrm{Cd}(\mathrm{II})$ ions for the exchangeable sites on the biosorbent surface and heavy metal ions were completely free in the extreme acidic conditions. With the increasing $\mathrm{pH}$ electrostatic attraction between the $\mathrm{Cd}(\mathrm{II})$ cation and negatively charged jute stick, the surface was increased. At higher $\mathrm{pH}$, electrostatic repulsion decreases due to a reduction of positive 
charge density on the sorption sites, thus resulting in an enhancement of metal adsorption [10]. A smaller decrease in removal at $\mathrm{pH}$ levels from 5 to 10 can be explained by the fact that the mobility of some elements may be reduced, leading to the precipitation of insoluble $\mathrm{Cd}(\mathrm{OH})_{2}$ at higher $\mathrm{pH}$ values. Therefore, the optimum $\mathrm{pH}$ of 4.5 is considered for all experiments of $\mathrm{Cd}(\mathrm{II})$ adsorption by JSP.

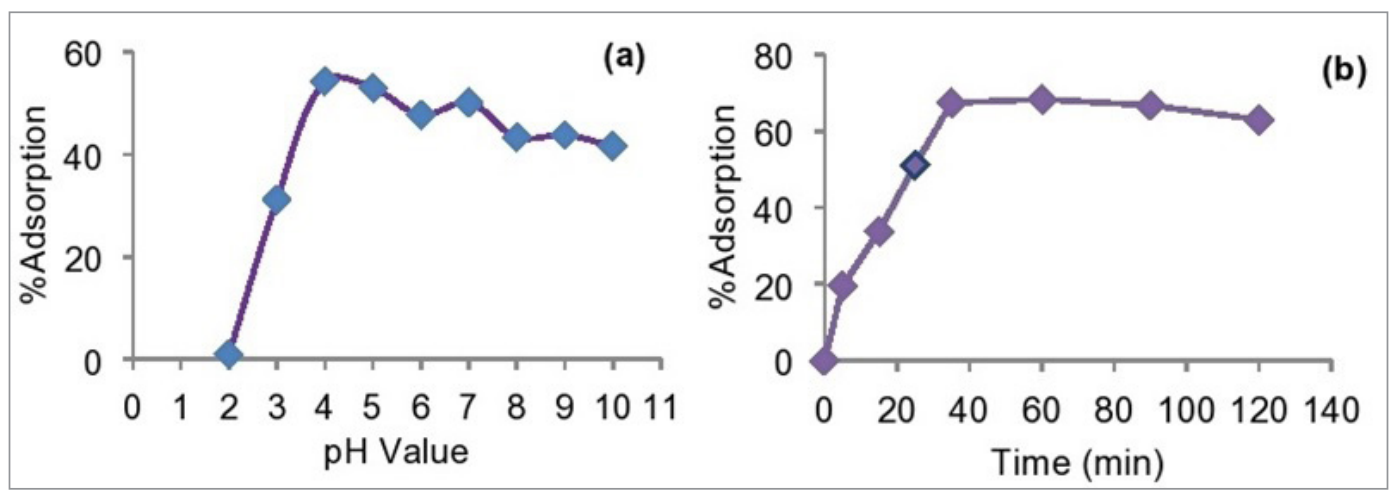

Figure 2. (a) Effect of $\mathrm{pH}$ on \% removal and (b) Effect of contact time on \% removal for biosorption of $\mathrm{Cd}(\mathrm{II})$ using $\mathrm{JSP}$ as biosorbent $\left(\mathrm{Ci}=50 \mathrm{mg} \mathrm{L}^{-1}\right.$; dose $\left.=0.5 \mathrm{~g} / 100 \mathrm{~mL}\right)$.

\section{Influence of contact time}

For the design of batch biosorption studies, the rate of biosorption is important. Figure 2(b) shows that the percentage biosorption of cadmium metal ions increases sharply to $67.34 \%$ with a rise in contact time up to 40 minutes at room temperature $\left(28^{\circ} \mathrm{C}\right)$. Equilibrium was reached quickly within $35-40$ minutes for $\mathrm{Cd}(\mathrm{II})$ biosorption and slightly increased or decreased afterwards. It is observed that a further increase in time did not cause a significant enhancement in the biosorption of the cadmium ions because, at that time, there is saturation of the active sites on the biosorbent. The maximum amount of cadmium (68.29\%) was adsorbed within 60 minutes, possibly as a result of an increased number of vacant sites available on the adsorbent surface. The adsorption process became slower with the progressive occupation of these sites, causing a decrease in the sorption capacity after 60 minutes since there were no more vacant sites for the metal ions to occupy [11]. Therefore, the optimum contact time was selected as 60 minutes for further experiments.

\section{Influencing of biosorbent amount}

Figure 3(a) shows that the adsorption of $\mathrm{Cd}(\mathrm{II})$ ions onto JSP increases with an increase in adsorbent dosage from $0.10 \mathrm{~g}$ to $1.25 \mathrm{~g}$, with a percentage removal from $32.316 \%$ to $88.914 \%$. This is because the ability of ion exchange sites, surface areas and the number of available adsorption sites for metal adsorption were higher as the dosage increased. However, an excessive increase in the adsorbent amount could cause a reduction in removal efficiency due to the formation of aggregates. Similar results were reported by Matakaet et al. [12], using Moringastenopetala and Moringaoleifera seed powders. By increasing Moringastenopetala powder dosage from 0.5 to $2.5 \mathrm{~g} / 100 \mathrm{~mL}$, the $\mathrm{Cd}$ (II) removal percentage was increased from about $20 \%$ to $58 \%$. On the other hand, Figure 3(b) illustrates a decreasing order in the amount of metal adsorbed $(\mathrm{mg})$ in each gram of adsorbent with the increase in adsorbent dosage from 0.10 to $1.25 \mathrm{~g} / 100 \mathrm{~mL}$. During the adsorption process, some adsorption sites may remain unsaturated, which can be attributed to the insufficiency of metal ions in solution with respect to available binding. Moreover, due to the increased biomass, the amount of unsaturated active sites was increased. However, it is notable that in Figure 3(b), with the increase of adsorbent dosages, the adsorption capacity was supposed to decrease sharply. However, this did not happen as there might have been some instrumental faults during the collection of datadata. 
(a)

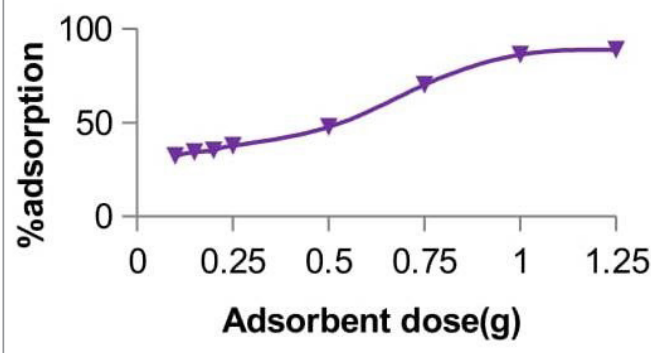

(b)

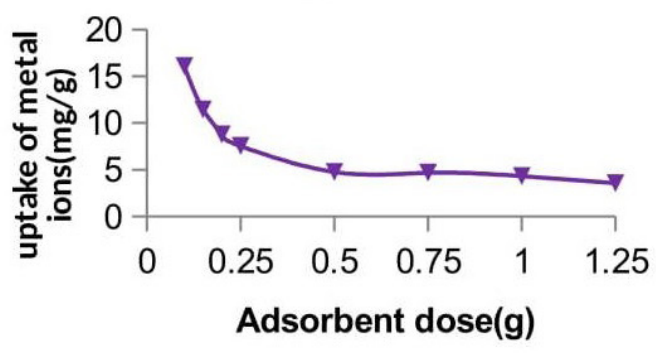

Figure 3. Influence of different adsorbent quantity on adsorption: (a) \% adsorption and (b) adsorption capacity $\left(\mathrm{mg} \mathrm{g}^{-1}\right)$ of JSP $\left(\mathrm{pH}=4.5\right.$, Contact time $=60 \mathrm{~min}$, Initial conc. of cadmium $\left.=50 \mathrm{mg} \mathrm{L}^{-1}\right)$.

\section{Influence of shaking speed on \% adsorption}

It was observed that with the increasing of agitation speed the percent removal increased while other parameters were kept constant. The adsorption efficiency was $63.85 \%$ at $80 \mathrm{rpm}$, reached at a maximum point $70.4 \%$ while it was $120 \mathrm{rpm}$ and then gradually decreased to $67.8 \%$ at $230 \mathrm{rpm}$. Because low speed could not spread the particles properly in the water by providing active binding sites for biosorption of metal ions. On the other hand, the high rpm value vigorously spreading the particles of jute stick powder in the water and did not allow sufficient time to bind with metal ions. With the incensement of rpm value the equilibrium reached quickly due to attaining of proper contact between metal ion and JSP in solution. Although mass transference speed increased with high shaking speed adsorption capacity was not increased tremendously due to accumulation of biosorbent at the bottom of water which buried the active binding sites. Similar result was reported by other authors described in literature [13].

\section{Influence of initial cadmium concentration of solution}

It was found that the adsorption percentage decreased from $64.44 \%$ to $50.02 \%$ with an increase in the initial concentration of cadmium from 20 to $100 \mathrm{mg} \mathrm{L}^{-1}$. The reason for this could be that the ratio of metal ions to active sites is low at low initial metal concentrations and a higher percentage was removed. In contrast, this ratio is relatively high at high initial metal concentrations. In other words, if the number of metal ions was much higher than the number of active sites available for adsorption, then a lower percentage would be removed. Therefore, the \% adsorption was rather low at high initial metal concentrations. On the other hand, the migration of $\mathrm{Cd}(\mathrm{II})$ ions into vacant sites of the sorbent increased due to the high initial $\mathrm{Cd}(\mathrm{II})$, resulting in the agglomeration of adsorbent particles at higher concentrations. It is leading to a decrease in the total surface area of the adsorbent particles available for adsorption.

\section{Adsorption isotherm}

The adsorption studies were conducted by changing the initial metal ion concentrations of $\mathrm{Cd}(\mathrm{II})$ at a fixed adsorbent dosage. The Freundlich, Langmuir, Temkin and D-R isotherms are shown graphically in Figure 4.

Langmuir isotherm constants $q_{m}$ and $K_{L}$ and the coefficient of determination $\left(R^{2}\right)$ are represented in Table I. Figure 4(a) shows that these isotherms were found to be linear, with high $\mathrm{R}^{2}$ values. The sorption constant, $\mathrm{K}_{\mathrm{L}}$ and the saturated monolayer sorption capacity, $\mathrm{q}_{\mathrm{m}}$ onto JSP were satisfactory. The values of $R_{L}$ indicated that the adsorption process was favorable because it was within the range $0<R_{L}<1$. The low value of $\mathrm{K}_{\mathrm{L}}$ obtained from the Langmuir isotherm indicated that Jute Stick powder has a high affinity for cadmium ion. 
Table I. Langmuir, Freundlich, Temkin and Dubinin-Radushkevich isotherm constants for biosorption of Cd(II) onto the JSP

\begin{tabular}{lccccc}
\hline Isotherm Model & \multicolumn{5}{c}{ Constants } \\
\hline \multirow{2}{*}{ Langmuir } & $\mathrm{q}_{\max }(\mathrm{exp})\left(\mathrm{mg} \mathrm{g}^{-1}\right)$ & $\mathrm{q}_{\max }(\mathrm{cal}).\left(\mathrm{mg} \mathrm{g}^{-1}\right)$ & $\mathrm{K}_{\mathrm{L}}\left(\mathrm{L} \mathrm{mg}^{-1}\right)$ & $\mathrm{R}_{\mathrm{L}}$ & $\mathrm{R}^{2}$ \\
& 10.004 & 14.28 & 0.030 & $(0.246-0.620)$ & 0.988 \\
\hline \multirow{2}{*}{ Freundlich } & - & - & $\mathrm{n}\left(\mathrm{g} \mathrm{L}^{-1}\right)$ & $\mathrm{K}_{\mathrm{F}}\left(\mathrm{mg} \mathrm{g}^{-1}\right)$ & $\mathrm{R}^{2}$ \\
& - & - & 1.485 & 0.674 & 0.992 \\
\hline \multirow{2}{*}{ Temkin } & - & - & $\mathrm{B}_{\mathrm{T}}\left(\mathrm{J} \mathrm{mol}^{-1}\right)$ & $\mathrm{A}_{\mathrm{T}}\left(\mathrm{L} \mathrm{g}^{-1}\right)$ & $\mathrm{R}^{2}$ \\
& - & - & 708.789 & 0.259 & 0.926 \\
\hline \multirow{2}{*}{$\mathrm{D}-\mathrm{R}$} & - & $\mathrm{q}_{\mathrm{m}}\left(\mathrm{mol} \mathrm{g}^{-1}\right)$ & $\mathrm{K}_{\mathrm{D}}\left(\mathrm{mol}^{2} / \mathrm{J}^{2}\right)$ & $\mathrm{E}\left(\mathrm{J} \mathrm{mol}^{-1}\right)$ & $\mathrm{R}^{2}$ \\
& - & 8.0285 & $1.00 \mathrm{E}-05$ & 0.223 & 0.865 \\
\hline
\end{tabular}

Figure 4(b) shows that plot of the Freundlich isotherm is a linear graph with a high coefficient of determination $\left(R^{2}=0.992\right)$. The values of Freundlich isotherm constant $n$ and $K_{F}$, representing the adsorption intensity and adsorption capacity $\left(\mathrm{L} \mathrm{g}^{-1}\right)$ are calculated from the slope and intercept of the curve presented in Table II. The results show that the $\mathrm{n}$ value (1.485) is between 1 and 10 , which represents a beneficial adsorption process [18].

Figure 4(c) illustrates the linear plot of Temkin isotherms, with a coefficient of determination of $R^{2}=$ 0.926. Temkin constants $A_{T}$ and $B_{T}$, which are related to the binding energy of the adsorbate and adsorbent, are summarized in the Table I indicating a physical adsorption. The values are at a satisfactory level, which confirms the adsorption of $\mathrm{Cd}(\mathrm{II})$ ions onto the JSP biosorbent [28].
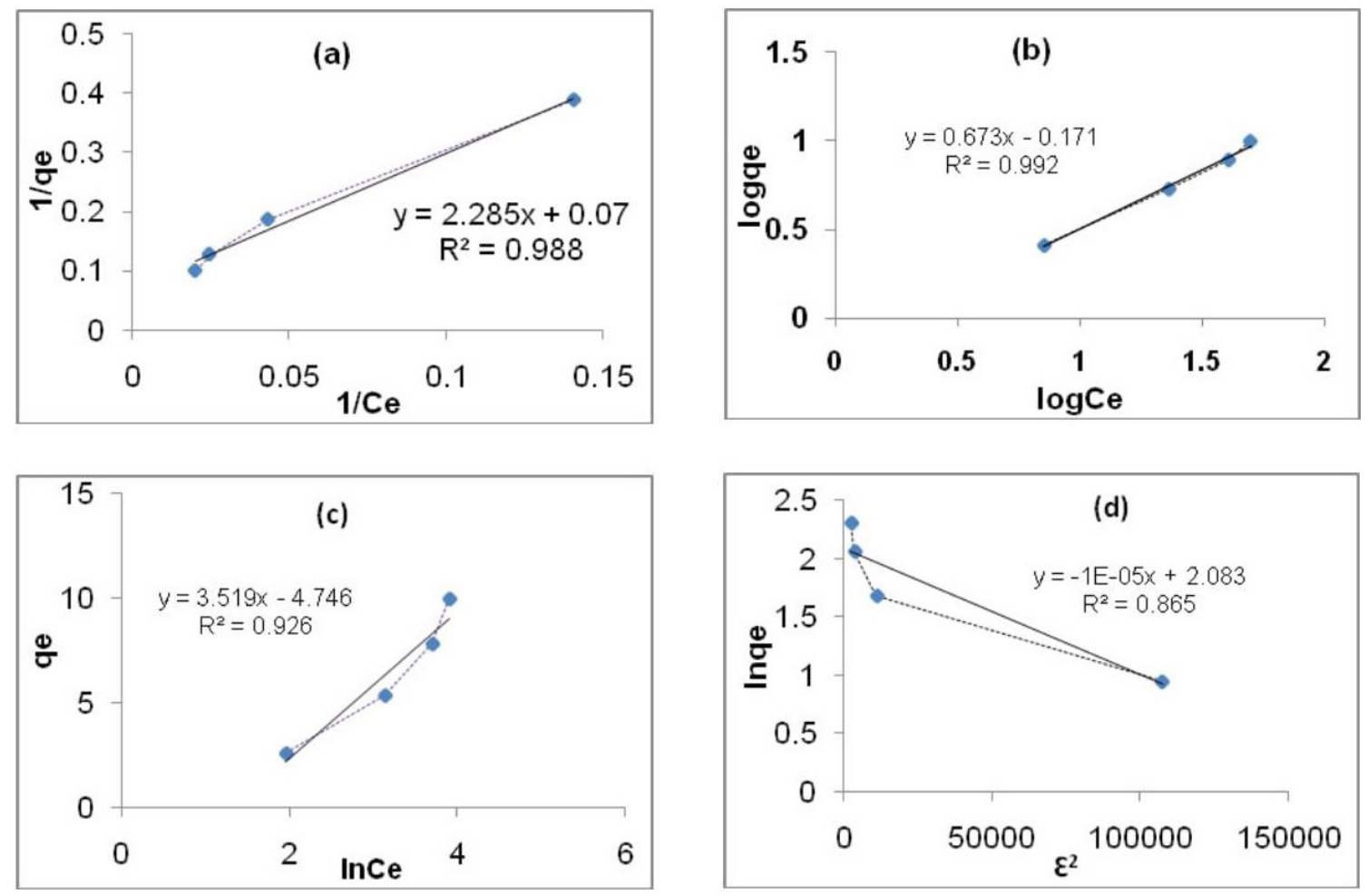

Figure 4. Plot of Adsorption isotherm models: (a) Langmuir (b) Freundlich (c) D-R and (d)Temkin for biosorption of $\mathrm{Cd}(\mathrm{II})$ onto the JSP ( $\mathrm{pH} 4.5$, biosorbent dose conc.: $0.5 \mathrm{~g} / 100 \mathrm{~mL}$, contact time: $60 \mathrm{~min}$, temperature: $28^{\circ} \mathrm{C}$. 
Table II. First and second-order kinetic model parameters for adsorption of Cd(II) onto JSP

\begin{tabular}{lcccc}
\hline Kinetic model & \multicolumn{4}{c}{ Parameters } \\
\hline \multirow{2}{*}{ Pseudo-first order } & $\mathrm{q}_{\mathrm{e}}$, exp. $\left(\mathrm{mg} \mathrm{g}^{-1}\right)$ & $\mathrm{q}_{\mathrm{e}}$, calc. $\left(\mathrm{mg} \mathrm{g}^{-1}\right)$ & $\mathrm{k}_{1}\left(\mathrm{~min}^{-1}\right)$ & $\mathrm{R}^{2}$ \\
& 6.83 & 7.585 & 0.0575 & 0.985 \\
\hline \multirow{2}{*}{ Pseudo-second order } & $\mathrm{q}_{\mathrm{e}}$, exp. $\left(\mathrm{mg} \mathrm{g}^{-1}\right)$ & $\mathrm{q}_{\mathrm{e}}$, calc. $\left(\mathrm{mg} \mathrm{g}^{-1}\right)$ & $\mathrm{k}_{2}(\mathrm{~g} / \mathrm{mg} / \mathrm{min})$ & $\mathrm{R}^{2}$ \\
& 6.83 & 7.87 & 0.0122 & 0.749 \\
\hline
\end{tabular}

The $D-R$ isotherm constant $q_{m}$ and $K_{D}$ are given in the Table I. The value of apparent energy (E) of adsorption found $0.223 \mathrm{kj} \mathrm{mol}^{-1}$ indicating a physical adsorption process between JSP and Cd(II) ions [29]. From the plot, the coefficient of determination $R^{2}$ is found to be 0.865 , indicating that this isotherm did not provide a very good fit to the experimental data.

It is concluded from the constant values and coefficient of determination that the Freundlich isotherm was the best fit for cadmium biosorption using Jute stick powder. It is in close agreement with the results shown by many authors discussed in literature [30]. The data found from the Freundlich isotherm suggest that the adsorption mechanism was physical and chemical processes, where $\mathrm{Cd}(\mathrm{II})$ ions are transported to the interior porous surface of JSP. It is assumed that chemical attraction to the heterogeneous surface with $\mathrm{Cd}(\mathrm{II})$ ions involves some energy change. After attaining thermodynamic equilibrium, no further net adsorption occurs between the solution and the adsorbent [31].

\section{Adsorption Kinetics}

The pseudo-first order and pseudo-second order kinetic models were investigated within the contact time of 0 to 120 minutes while keeping other parameters constant, such as the concentration of $\mathrm{Cd}$ (II) 50 $\mathrm{mg} \mathrm{L}^{-1}$, adsorbent dose $0.5 \mathrm{~g} / 100 \mathrm{~mL}, \mathrm{pH} 4.5$ and shaking speed $180 \mathrm{rpm}$. Figure 5(a, b) shows the plot of both kinetic models and Table II summarizes the rate constant and other parameters. The results show that the equilibrium sorption capacities qe(cal.) determined using the pseudo-first-order and pseudo-secondorder models are almost in agreement with the experimental qe(exp) values. However, the values of rate constant and coefficient of determination $\left(R^{2}=0.985\right)$ of pseudo-first-order are higher than those of the pseudo-second-order model. The mechanism of adsorption is assumed to involve $\mathrm{Cd}(\mathrm{II})$ being adsorbed by proper diffusion, making a layer through the boundary of the JSP surface. Besides, chemisorption also happened in the removal of $\mathrm{Cd}(\mathrm{II})$, but physisorption might be predominant over chemisorption [32]. Therefore, the pseudo-first-order kinetic model was the best described model for the adsorption of Cd(II) onto the JSP biosorbent.

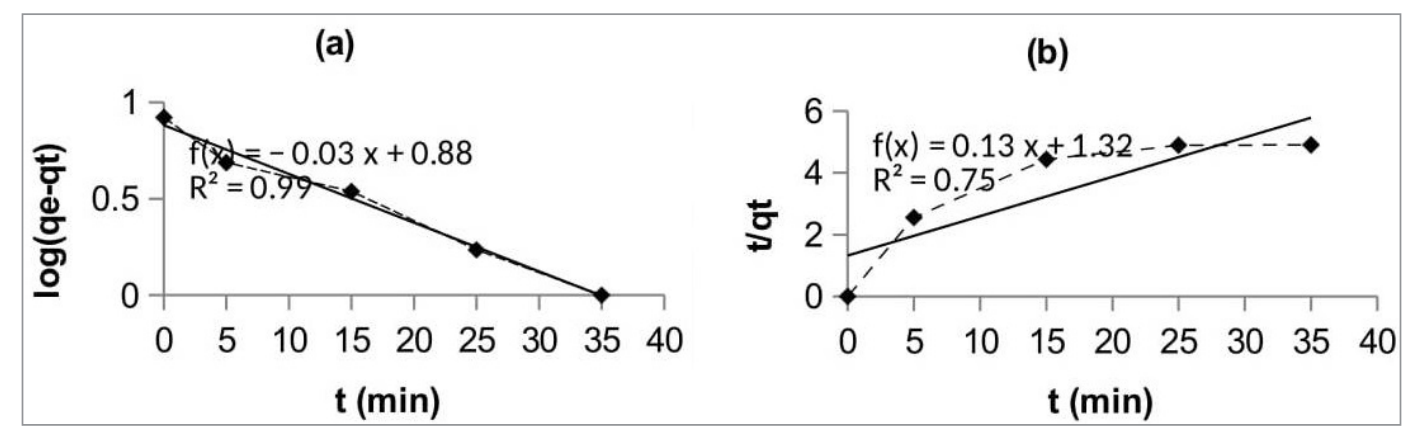

Figure 5. Plot of adsorption kinetic models: (a) pseudo-first-order equation, (b) pseudosecond-order equation, for biosorption of $\mathrm{Cd}(\mathrm{II})$ by JSP. 


\section{Equilibrium sorption spontaneity studies}

In the experimental working process, all experiments were carried out at room temperature $\left(28^{\circ} \mathrm{C}\right)$, maintaining the optimum temperature. In order to reveal the spontaneity of the equilibrium adsorption process of $\mathrm{Cd}(\mathrm{II})$ onto the JSP, the thermodynamic parameter Gibbs free energy change was calculated using Equation 13. The biosorption process is considered equilibrium reactions between the adsorbate and adsorbent. For such equilibrium reactions, the distribution constant, $\mathrm{Kc}$, is used to evaluate the thermodynamic parameter $\left(\Delta \mathrm{G}^{\circ}\right)$ since it depends on temperature. It is calculated using Equation 12:

$$
K_{C}=\frac{\mathrm{Cad}}{\mathrm{Ce}}
$$

Where $\mathrm{Kc}$ is related to change in free energy expressed by Equation 4.

$$
\Delta \mathrm{G}^{\circ}=-\mathrm{RT}_{\ln } \mathrm{K}_{\mathrm{C}}
$$

Where, $\mathrm{Kc}$ is the thermodynamic equilibrium constant and is used to calculate Gibbs free energy; $\mathrm{C}_{\mathrm{ad}}=$ $\mathrm{mg}$ of adsorbate adsorbed per liter; $\mathrm{C}_{\mathrm{e}}=$ the equilibrium concentration of solution, $\mathrm{mg} \mathrm{L}^{-1} ; \mathrm{R}$ is the universal gas constant $(8.314 \mathrm{~J} / \mathrm{mol} / \mathrm{K})$ and $\mathrm{T}$ is the reaction temperature in Kelvin $(301 \mathrm{~K})$. Table III shows the calculated Gibbs free energy change with negative value for a range of initial concentrations, confirming the feasibility and spontaneous nature of the biosorption process.

Table III. For different initial concentration of Cd(II), calculated values of Gibbs free energy

\begin{tabular}{cccc}
\hline $\begin{array}{c}\text { Initial concentration } \\
\mathbf{C}_{0}\left(\mathbf{m g ~ L}^{-1}\right)\end{array}$ & $\begin{array}{c}\text { Equilibrium } \\
\text { concentration } \\
\mathbf{C}_{\mathrm{e}}\left(\mathbf{m g ~ L}^{-1}\right)\end{array}$ & $\begin{array}{c}\text { Amount adsorbed } \\
\mathbf{C}_{\text {ad }}\left(\mathbf{m g ~ L}^{-1}\right)\end{array}$ & $\Delta \mathrm{G}^{\circ}{ }_{\text {ad }}\left(\mathbf{J ~ m o l}^{-1}\right)$ \\
\hline 20 & 7.111 & 12.889 & -488.02 \\
50 & 23.164 & 26.836 & -368.16 \\
80 & 38.79 & 41.21 & -151.42 \\
100 & 49.976 & 50.024 & -2.4 \\
\hline
\end{tabular}

\section{Desorption of metal ions and reusability of biosorbent}

It is important to desorb the metal ions and regenerate the adsorbent used to make the process economically feasible. The desorption studies were carried out by batch process using $0.1 \mathrm{M} \mathrm{HCl}, 0.1 \mathrm{M}$ $\mathrm{HNO}_{3}, 0.1 \mathrm{M} \mathrm{NaOH}, 0.1 \mathrm{M} \mathrm{NaCl}$, and distilled water. The percentage recovery of $\mathrm{Cd}$ (II) obtained with $\mathrm{HCl}$ $0.1 \mathrm{M}(86.49 \%)$ was higher than with the other solutions. It was observed that $0.1 \mathrm{M} \mathrm{NaOH}$ and distilled water desorbed $\mathrm{Cd}(\mathrm{II})$ ions to a very small amount. The desorption of metal ions with acidic solution is greater, indicating that adsorption in low $\mathrm{pH}$ is less and metal ions are exchanged by hydrogen ions. Similar results were also reported by several researchers using different agro-based biosorbents [33]. As $0.1 \mathrm{M} \mathrm{HCl}$ is most efficient to regenerate the biosorbent, it was used to investigate the desorbing agent four times. For the study of desorption, $0.5 \mathrm{~g}$ of $\mathrm{Cd}$ (II) loaded JSP was kept in contact with $100 \mathrm{~mL}$ of $0.1 \mathrm{M} \mathrm{HCl}$ for $60 \mathrm{~min}$ and the desorbed acidic solution was subjected to atomic absorption spectrometry to determine the metal concentration. Five successive cycles of adsorption and desorption were investigated and the efficiency was found to be almost unchanged for the first three cycles and then gradually reduced for the fourth and fifth cycles (Figure 6). The regenerated JSP could be used three times with only minor efficiency loss. Functional groups described in IR analysis and structural porosity are important for the adsorption and desorption processes. These adsorbing sites in the structure of JSP may cause damage for recurrent use with a desorbing agent $(0.1 \mathrm{M} \mathrm{HCl})$ resulting in less efficiency after three or four times. 


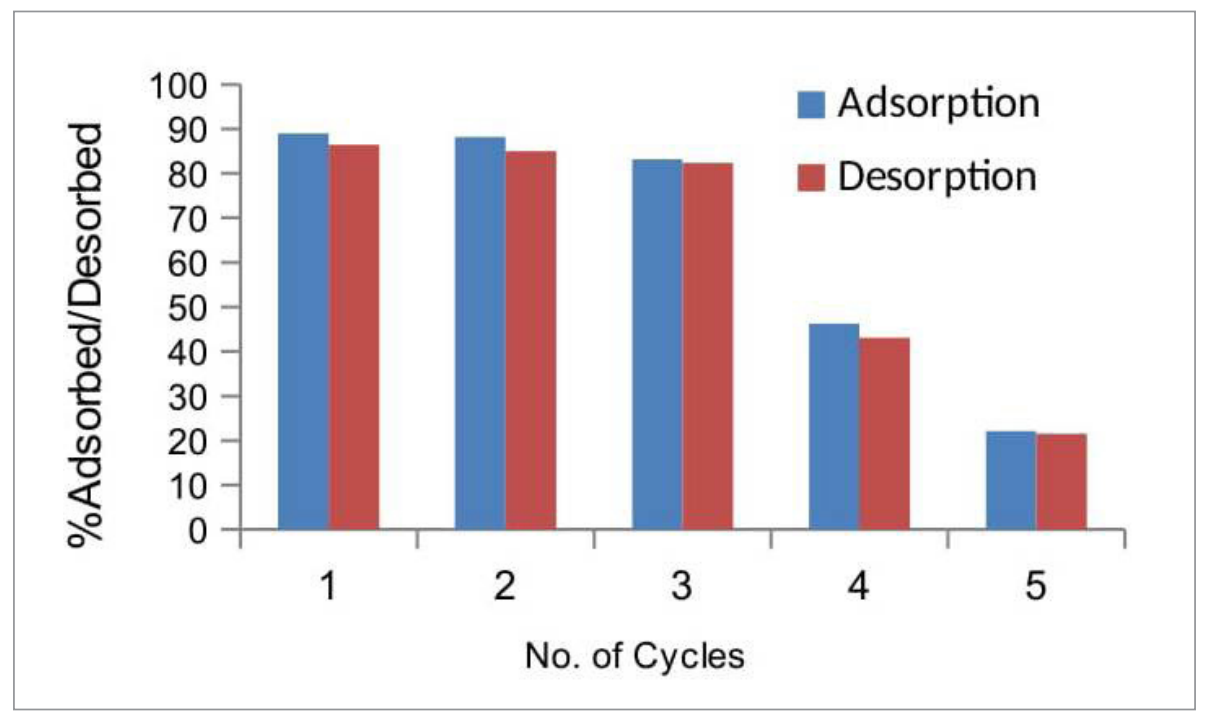

Figure 6. Biosorption and desorption cycles for $\mathrm{Cd}(\mathrm{II})$ onto JSP using $0.1 \mathrm{M} \mathrm{HCl}$ as desorbing agent.

\section{CONCLUSION}

The biosorption of $\mathrm{Cd}(\mathrm{II})$ by Jute Stick powder biomass is found to be influenced by the solution $\mathrm{pH}$, biosorbent dose, contact time, temperature and initial metal ion concentration. The sorption data were fitted to Langmuir, Freundlich, Temkin and Dubunin-Radushkevich isotherms, of which, the Freundlich adsorption model was found to be the best fit with the aspects of highest regression value and other parameters. The kinetic studies indicate that the biosorption process follows pseudo-first-order and pseudo-second-order models, but that the pseudo-first-order model was better for interpreting kinetic data. The biosorbent Jute Stick powder can be regenerated and reused successfully more than three times. The values of the thermodynamic parameters show the spontaneous nature of the biosorption of $\mathrm{Cd}(\mathrm{II})$ from aqueous solution. Compared to the other low cost agricultural biosorbents from the literature (Table IV), the adsorption capacity of JSP is high. This is because the current biosorbent consists of an adequate number of acidic groups, and carboxyl and hydroxyl groups from the IR study. Jute Stick has no or little economic value, and is readily available, which strengthens its future use as a cost-effective adsorbent for the elimination of toxic heavy metals from aqueous solutions.

Table IV. A comparison of different low cost adsorbents in terms of Cd(II) metal ion adsorption capacities $\left(q_{\max }\right)$

\begin{tabular}{llll}
\hline Biosorbent & $\mathbf{p H}$ & $\mathbf{q}_{\max }$ & Reference \\
\hline Tea waste & 5 & 1.76 & {$[4]$} \\
Almond shell & $5-6$ & 7.19 & {$[34]$} \\
Caulerpa lentillifera & 5 & 4.7 & {$[35]$} \\
Gas industry sludge-based adsorbent & 5 & 25 & {$[36]$} \\
Chemically modified Sorghum bicolor & $5-6$ & 17.2 & {$[35]$} \\
JSP & $4-5$ & 10 & This study \\
\hline
\end{tabular}

\section{Acknowledgement}

The authors thank the department of Chemistry, University of Chittagong for giving support by providing AAS, FTIR and other chemicals and equipment facilities. Also, the authors are grateful to the research and publication cell of University of Chittagong for their partial financial support to conduct the project. 
Funding: Research and Publication Cell, University of Chittagong, Bangladesh partially funded the project.

Conflict of interest: The authors declare that they have no conflict of interest.

\section{REFERENCES}

1. Kazi, T. G.; Jalbani, N; Kazi, N; Jamali, M. K; Arain, M. B.; Afridi, H. I.; Kandehro, G. A.; Pirzado, Z. Renal Failure, 2008, 30, pp 737-745.

2. El-Sayed, G. O.; Dessouki, H. A.; Ibrahim, S. S. Chem. Sci. J., 2010, 9, pp 1-11.

3. Babalola, J.; Overah, L. C. O.; Babarinde, A.; Oninla, O. V.; Olatunde, A. J. Appl. Sci. Environ. Manage, 2011, 15 (4), pp $607-615$.

4. Ghasemi, S.; Gholami, R. M.; Yazdanian, M. Jundishapur J. Health. Sci., 2017, 9 (1), p e37301.

5. Tabatabaee, A.; Dastgoshadeh, F.; Tabatabaee, A. Int. J. Environ. and Ecol. Eng., 2014, 8 (9), pp 699-704.

6. Awwad, M. A.; Salem, M. N. J. Saudi. Chem. Soc., 2011, 18, pp 486-493.

7. Uddin, M. N.; Alam, J.; Naher, S. R. Euro. J. Chem., 2018, 9 (3), pp 202-212.

8. Alam, J.; Uddin, M. N. Euro. J. Chem., 2019, 10 (4), pp 295-304.

9. Módenes, de A. N.; Pietrobelli, J. M.T. A.; Espinoza-Quiñones, F. R. Water Sci. Technol., 2009, 60, pp $293-300$.

10. Lu, D.; Cao, Q.; Li, X.; Cao, X.; Luo, F.; Shao, W. Hydrometallurgy, 2009, 95, pp 145-152.

11. Bishnoi, N. R.; Kumar, R.; Kumar, S.; Rani, S. J. Hazard. Mater, 2007, 135 (1), pp 142-147

12. Mataka, L. M.; Henry, E. M. T.; Masamba, W. R. L.; Sajidu, S. M. Int. J. Environ. Sci. Tech., 2010, 3, pp $131-139$.

13. Bulut, Y.; Tez, Z. J. Environ. Sci., 2007, 19 (2), pp 160-166.

14. Kyzas, G. Z.; Matis, K. A. J. Mol. Liq., 2015, 203, pp 59-168.

15. Langmuir, I. J. Am. Chem. Soc.,1916, 38, pp 2221-2295.

16. McKay, V.; Ho, Y.S.; Porter, J. F. Water Air Soil Pollut., 2002, 141 (1-4), pp 1-33.

17. Freundlich, H. M. F. Z. Phys. Chem., 1906, 57, pp 385-470.

18. Kadirvelu, K.; Namasivayan, C. J. Emerg. Trend. Eng. Appl. Sci., 2012, 3 (2) pp 254-258.

19. Ringot, D.; Lerzy, B.; Chaplain, K.; Bonhoure, J. P.; Auclair, E.; Larondelle, Y. Bioresour. Technol., 2007, 98 (9), pp 1812-1821.

20. Dubinin, M. M.; Radushkevich, L.V. Proc. Acad. Sci. Phys. Chem. USSR, 1947, 55, pp 331-333.

21. Vijayaraghavan, K.; Padmesh, T. V. N.; Palanivelu, K.; Velan M. J. Hazard. Mater, 2006, 133 (1-3), pp $304-308$.

22. Lagergren, S.; Svenska, B. K. R. Swed. Acad. Sci. Doc. Band, 1898, 24, pp 1-13.

23. Ho, Y. S.; McKay, G. Proc. Biochem., 1999, 34, pp 451-465.

24. Sinha, E.; Rout, S. K. Bull Mater Sci., 2009, 32 (1), pp 65-76.

25. Anandkumara, J.; Mandal, B. J. Hazard. Mater., 2009, 168, pp 633-640.

26. Pérez-Marín, A. B.; Zapata, V. M.; Ortuno, J. F.; Aguilar, M. J. S. J. Hazard. Mater., 2007, 139, pp $122-131$.

27. Iqbal, M.; Saeed, A.; Zafar, S. I. J. Hazard. Mater., 2009, 164, pp 161-171.

28. Dada, A. O.; Olalekan, A. P.; Olatunya, A. M. IOSR-JAC, 2012, 3 (1), pp 38-45.

29. Sivakumar, P.; Palanisamy, P. N. Int. J. Chem. Tech. Res., 2009, 1 (3), pp 502-510.

30. Dawodu, F. A.; Akpomie, G. K.; Ogbu, I. C. Int. J. of Multidisc. Sci. and Eng., 2012, 3 (9), pp 9-14.

31. Weber, S. S. Drug Intell. Clin. Pharm., 1985, 19 (1) pp 69-69.

32. Nipa, S. T.; Rahman, Md. W.; Saha, R.; Hasan, Md. M.; Deb, A. Desalin. Water Treat., 2019, 153, pp $279-287$.

33. Prince, C.; Isaac, J.; Sivakumar, A. Desalin. Water Treat., 2013, 51 (40-42), pp 7700-7709.

34. Mehrasbi, M. R.; Farahmandkia, Z.; Taghibeigloo, B.; Taromi, A. Water Air Soil Pollut., 2009, 199 (1-4), pp 343-351.

35. Pavasant, P.; Apiratikul, R.; Sungkhum, V.; Suthiparinyanont, P.; Wattanachira, S.; Marhabad, T. F. Biores. Technol., 2006, 97 (18), pp 2321-2329.

36. Praveen, K.; Pawan, K.; SN Appl. Sci., 2019, 1, p 365. 